\title{
Phytoplankton biodiversity changes in a shallow tropical reservoir during the hypertrophication process
}

\author{
Crossetti, LO. ${ }^{\mathrm{a}}$, Bicudo, DC. ${ }^{\mathrm{a}}$, Bicudo, CEM. ${ }^{\mathrm{a} *}$ and Bini, LM. ${ }^{\mathrm{b}}$ \\ a'Seção de Ecologia, Instituto de Botânica, \\ Av. Miguel Stéfano, 3687, CEP 04301-012, São Paulo, SP, Brazil \\ 'bepartamento de Biologia Geral, Universidade Federal de Goiás - UFG, \\ CP 131, CEP 74001-970, Goiânia, GO, Brazil \\ *e-mail: cbicudo@terra.com.br
}

Received November 21, 2007 - Accepted November 21, 2007 - Distributed November 30, 2008

(With 4 figures)

\begin{abstract}
Study aimed at evaluating phytoplankton biodiversity changes in a shallow tropical reservoir during its hypertrophication process. Samplings were carried out monthly during 8 consecutive years (1997-2004) in 5 depths. Conspicuous limnological changes in the reservoir derived from the presence and/or removal of the water hyacinth, characterized 3 different phases. Over the time series, reservoir changed from a typical polymictic eutrophic system to hypertrophic one, leading to a reduction of approximately 70 species (average 37\%). Chlorophyceae accounted for the highest species richness (46\%) among all algal classes and strictly followed total species richness variation. Internal feedback mechanisms intensification over phase III clearly promoted the sharp decrease in biodiversity. Highest decreases, mainly during springs, occurred simultaneously to the highest Cyanobacteria blooms. Increased turbidity due to heavy phytoplankton blooms suppressed all other algal groups, so that at the end of the present study even Cyanobacteria species richness decreased. Total dissolved phosphorous was included in most of the best selected models used to analyze the temporal patterns in species richness loss. Present data show that biodiversity loss following trophic change was not a single dimension of a single factor but, rather, a template of factors (e.g. light, stability) co-varying in consequence of the larger levels of biomass supported in the reservoir.
\end{abstract}

Keywords: biodiversity loss, Cyanobacteria bloom, phosphorus, species richness, water hyacinth.

\section{Mudanças na biodiversidade fitoplanctônica em um reservatório tropical raso durante o processo de hipereutrofização}

\begin{abstract}
Resumo
Estudo avaliou as mudanças na biodiversidade da comunidade fitoplanctônica em um reservatório tropical raso durante processo de hipereutrofização. Foram realizadas amostragens mensais durante oito anos consecutivos (19972004) em cinco profundidades. Mudanças limnológicas conspícuas no reservatório foram a conseqüência da presença e/ou remoção do aguapé, caracterizando três fases limnológicas. Durante a série temporal, o reservatório mudou de um sistema eutrófico polimítico típico para um sistema hipereutrófico, levando à redução de aproximadamente 70 espécies (média de 37\%). Chlorophyceae foi a classe com a maior riqueza de espécies (46\%) entre todas e seguiu, intimamente, a variação da riqueza total de espécies. A intensificação dos mecanismos internos de retroalimentação durante a fase III claramente promoveram uma acentuada queda da biodiversidade. Os decréscimos mais acentuados, especialmente durante as primaveras, ocorreram simultaneamente às maiores florações de Cyanobacteria. $\mathrm{O}$ aumento de turbidez provocado pelas florações maciças suprimiu outros grupos de algas de forma que, no final do presente estudo, até mesmo a riqueza de Cyanobacteria decaiu. Fósforo total dissolvido foi incluído na maioria dos melhores modelos selecionados para análise dos padrões temporais da perda da biodiversidade. Os presentes dados mostram que a perda da biodiversidade durante a mudança trófica não esteve relacionada a apenas um fator, mas a um conjunto deles (exemplos: luz, estabilidade), que co-variaram em consequiência dos elevados níveis de biomassa mantidos pelo reservatório.
\end{abstract}

Palavras-chave: aguapé, floração de cianobactérias, fósforo, perda de biodiversidade, riqueza de espécies. 


\section{Introduction}

Finding factors that control species richness and diversity is a major task for ecologists, some empirical or theoretical rules being published as a result of such interest (Dodson et al., 2000; Rodrigo et al., 2003; Thomaz et al., 2003). Freshwater makes up only $0.01 \%$ of the World's water and around $0.8 \%$ of the Earth's surface, yet this tiny fraction of global water supports at least 100,000 species out of approximately 1.8 million, i.e. almost $6 \%$ of all described species (Dundgeon et al. 2006). Freshwater biodiversity inventories are mostly incomplete in many parts of the World, especially in the tropics, and species' loss rates may be higher than currently estimated (Dudgeon et al., 2006). In this respect, Brazilian inland waters are of enormous global significance for algal biodiversity (25\% of the World's species) (Agostinho et al., 2005).

Freshwater biodiversity loss due to increase in nutrient concentration was already discussed elsewhere (Leibold, 1999; Dodson et al., 2000; Dudgeon et al., 2006). This fact was already pointed out in studies conducted in Brazilian inland waters (Martinelli et al., 2002; Barbosa et al., 1993; Tundisi, 2003; Tundisi and Matsumura-Tundisi, 2003; Agostinho et al., 2005). However, long-term studies on biodiversity changes due to eutrophication are still unavailable for tropical inland waters.

Emergent properties of phytoplankton assemblages, notably species richness, are under constant change due to spatial and temporal variability in biotic and abiotic as well as to internal and exogenous drivers (Reynolds et al., 1993). Under the influence of effluents, that causes increasing nutrient availability, one may expect different trajectories of phytoplankton species richness depending on the magnitude of loads and the time-span of the study. After a critical point, eutrophication may cause a catastrophic shift in the aquatic ecosystem properties (Scheffer, 2001), and biodiversity loss may be expected. Despite all progress already experienced in understanding the eutrophication process, complex relationships among causes and consequences and the effect of feedback mechanisms, leading to alternative states, represent a challenge to the planning of systems' restoration strategies with that type of dynamic (Suding et al., 2004).

In two previous long-term (eight years) studies (Bicudo et al., 2006; 2007), the conspicuous changes in the limnological characteristics of a shallow tropical system (Garças Reservoir) derived from the water hyacinth removal was shown. Garças Reservoir was a typical eutrophic polymictic system long before the macrophyte removal turning, however, into hypertrophic after the intervention according to different trophic indices and classification schemes (Bicudo et al., 2006). The longterm phosphorus dynamics in the system, initially driven by the allochthonous nutrient loading, was replaced by internal ecological processes, when feedback mechanisms driven by Cyanobacteria blooms enhanced water stability and oxygen anoxia at the reservoir bottom, thus increasing suitable conditions for phosphorus internal loading and leading to a switch to a degraded state (Bicudo et al., 2007).

This study aimed at evaluating how those conspicuous changes affected phytoplankton species richness in the reservoir. We also evaluated how simple models based on phytoplankton biomass and nutrient availability were able to account for the temporal patterns in phytoplankton species richness.

\section{Methods}

\subsection{Study area}

Garças Reservoir $\left(23^{\circ} 38^{\prime} \mathrm{S}\right.$ and $\left.46^{\circ} 37^{\prime} \mathrm{W}\right)$ is located in the Parque Estadual das Fontes do Ipiranga Biological Reserve (São Paulo, southeast Brazil). Reserve contains one of the largest remnants of Atlantic Forest in a highly populated urban area. Reservoir has the surface area of $88,156 \mathrm{~m}^{2}$ and holds the volume of $188,785 \mathrm{~m}^{3}$. The mean and maximum depths are $2.1 \mathrm{~m}$ and $4.7 \mathrm{~m}$, respectively. Mean theoretical residence time is 71 days. Based on an eight years time series, Bicudo et al. (2007) recognized three phases of the reservoir, which were characterized by the water hyacinth cover, as well as physical, chemical and biological characteristics of the system. Briefly, phase I (January 1997-March 1998) was characterized by a gradual increase of the water hyacinth cover (up to $20 \%$ of the water surface) and the presence of cyanobacterial blooms during the spring. Phase II (April 1998August 1999) was defined by the rapid expansion of the macrophyte cover (40-70\% of the water surface). Phase III (September 1999-December 2004) was triggered within three months after the macrophyte removal, and is characterized by the abrupt change to a degraded state with permanent cyanobacterial blooms.

\subsection{Sampling and abiotic and biological variables}

Samplings were performed monthly from 1997 to 2004 at the reservoir deepest site $(4.7 \mathrm{~m})$ in 5 depths (subsurface, 1, 2, $3 \mathrm{~m}$ and $\pm 30 \mathrm{~cm}$ from the sediments). Variables studied and analytical procedures used were described in detail in earlier contributions (Bicudo et al., 2006; 2007).

Taxonomic analysis of phytoplankton was conducted at least to the species level. Specific richness evaluation was based on the quantification procedure (Utermöhl, 1958) to standardize analyses efforts.

\subsection{Data analyses}

In order to select the best approximating ordinary least square (OLS) regression model for each response variable (total species richness and species richness of different algal groups for the water column), Akaike's Information Criterion ( $\mathrm{AIC}_{\mathrm{c}}$, second-order $\mathrm{AIC}$, corrected for small sample sizes) was calculated. As recommended by Burnham and Anderson (2002: 71), AIC differences $\left(\Delta_{\mathrm{i}}\right)$ were calculated over all candidate models 
in the set. Model's plausibility decreased with increasing $\Delta_{i}$ and, therefore, this quantity offers the level of empirical support for a given model (see Burnham and Anderson, 2002: 70). Values of $\Delta_{\mathrm{i}}<3$ indicate models with similar levels of empirical support, values between three and 10 some uncertainty, whereas values $>10$ may be clearly discarded. Note that these rules apply independently of the absolute scale of $\mathrm{AIC}_{\mathrm{c}}$ values (that, in turn, is a function of the scale of the response variable). Finally, $\Delta_{i}$ values were also used to compute Akaike's weight of each model $\left(\mathrm{w}_{\mathrm{i}}\right)$, which provides evidence that the model is actually the best explanatory one. These values of $\mathrm{w}_{\mathrm{i}}$ are usually standardized by their sum across all models evaluated, so they are dependent on the set of models used.

An important advantage for using model selection criteria is that they allow inferences from more than one model, what is not possible when other traditional approaches (i.e., fit maximization and null hypothesis testing) are used (Johnson and Omland, 2004). In addition, model selection is especially valid for making inferences from observational data, when the latter are collected from complex systems (Johnson and Omland, 2004), as in the present study. All analyses were carried out in the model selection module recently implemented in SAM software (Rangel et al., 2006).

\section{Results}

\subsection{Biological variables}

351 species in total, distributed in 11 algal classes, were identified over the study period. Chlorophyceae included the highest number of taxa (148 species or equivalent to $42 \%$ of total species identified), followed by Euglenophyceae (52 species, 15\%) and Cyanobacteria (40 species, 11\%).

A conspicuous decrease in species richness was mainly detected over the time series, not along the reservoir depth profile (Figure 1), its highest value recorded during phase I (January 1997) at $2 \mathrm{~m}$ (104 taxa) and the lowest one in phase III (December 2003) at the surface (3 taxa).
Considering community species richness in the water column (total species richness), highest and lowest fluctuation over time occurred in phases III and II, respectively. Species numbers fluctuated from 143 (beginning of phase I) to 19 species (phase III, May 2004) (Figure 2a). Mean total species richness dropped sharply over the phases (111 in phase I, 83 in phase II and 41 in phase III).

Chlorophyceae accounted for the highest species richness among all algal classes over the entire time series (mean contribution $=46 \%, n=96$ ), and strictly followed total species richness variation (Figure 2a). Cyanobacteria were the second important class, but different from total species richness it increased in biodiversity from phase II until the first two years of phase III (Figure 2b).

In general, phase I presented the highest species richness values for the majority of phytoplankton classes, and the main decrease in total biodiversity over the time series (March 1998, September 1999 and SeptemberOctober 2002, 2003) was followed by a sharp decrease of all algal classes (Figures 2a,b). An exception was detected during the spring of 2000 (September-November), when the Cyanobacteria richness displayed an opposite trend comparing to all remaining classes in the reservoir.

\subsection{Integrated analysis of biological and abiotic variables}

An auto-covariate was added to each model presently used in order to take temporal autocorrelation into account. Results obtained for total species richness indicated that the best model included TN and TDP (Table 1). The second best-model involved the same variables considered for the best model plus water stability (temperature differences between surface and mean depth: $2.5 \mathrm{~m}$ ). Among the models estimated to explain Bacillariophyceae richness, the best one selected by AIC $c$ included variables $\mathrm{CO}_{2}$, TN, TDP, water stability, $\mathrm{SiO}_{4}$, and the autoregressive covariate. The first two models selected for Chlorophyceae were formed by TDP

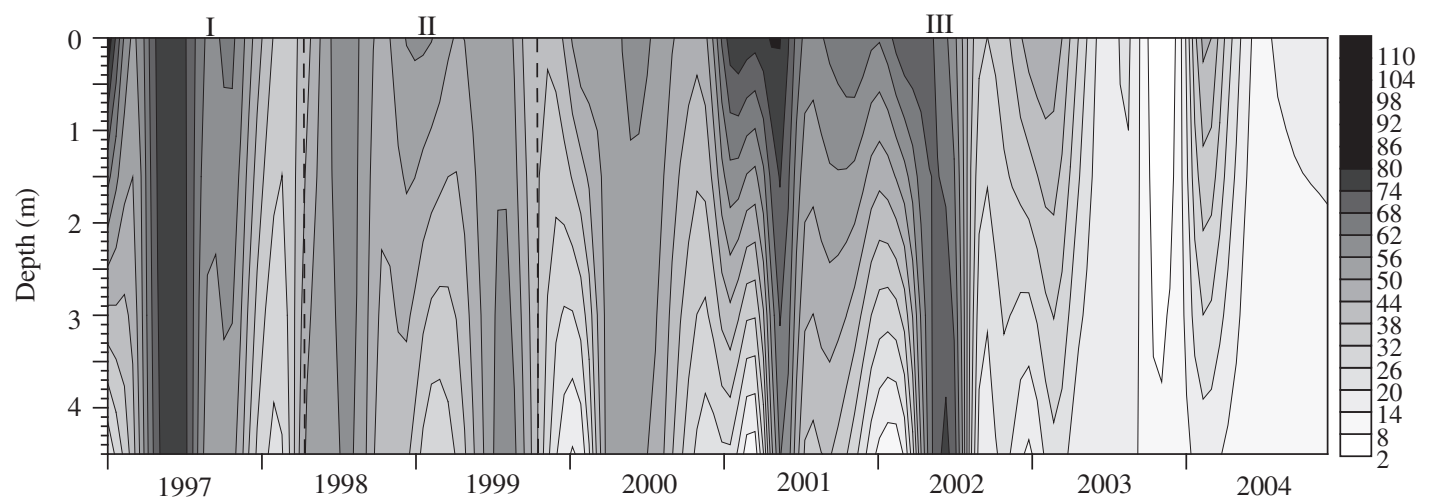

Figure 1. Depth-time diagram of species richness recorded over 8 years in the Garças Reservoir. Vertical dashed lines indicate the end of each phase. 

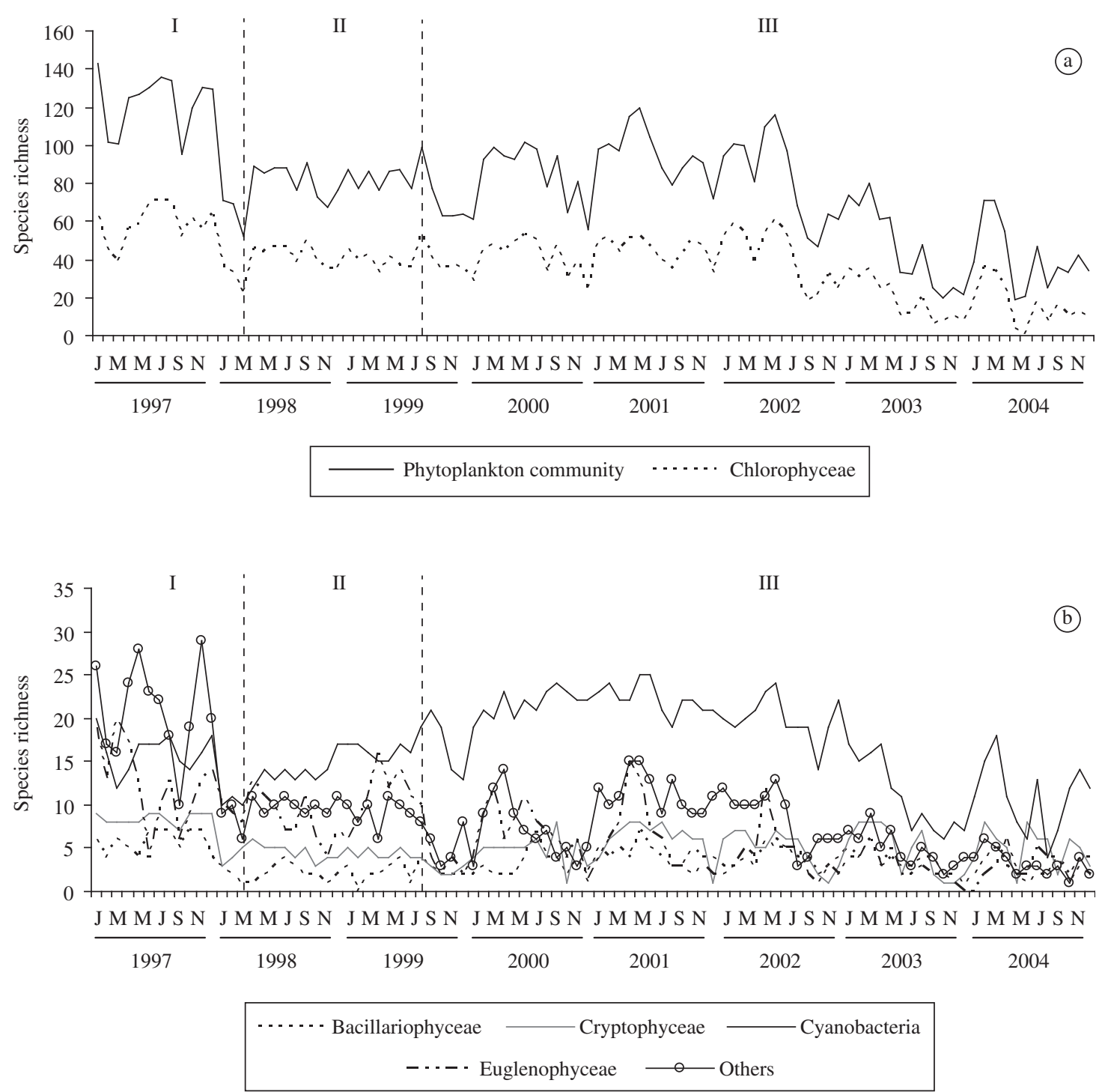

Figure 2. Temporal trends in phytoplankton species richness recorded over 8 years in the Garças Reservoir. The same are shown for other algae classes. Vertical lines indicate the end of each phase.

and, again, by the latter variable and TN, respectively. The best-model selected for Cryptophyceae was formed by the following predictors: $\mathrm{CO}_{2}$, TDP and water stability, whereas TN was also incorporated in the second-best model. The best approximating model for Cyanobacteria richness was the one including TDP and chlorophyll- $a$, whereas the second-best model was modified by the inclusion of TN. Models that included $\mathrm{CO}_{2}, \mathrm{TN}$ and TDP and the isolated effect of $\mathrm{CO}_{2}$ and TDP were, respectively, the best and the second-best model for Euglenophyceae species richness. The following main predictors were included in the best-selected model for species richness of all other algal groups: TN, TDP and chlorophyll- $a$. Only chlorophyll- $a$ was selected in the second-best model.

However, it is important to emphasize that Akaike weights for these models (Table 1), relative to the weights for the other models, were not large. For in- stance, evidence ratios for the best-models against the next-best models $\left(\mathrm{w}_{1} / \mathrm{w}_{2}\right)$ were all lower than 2.5. Such results indicate a high level of model selection uncertainty, even though they all highlighted TDP as a key factor explaining the decrease in species richness in the reservoir (Figure 3). Figure 4 shows the sharp increase in TDP over the time series, particularly during the third phase.

\section{Discussion}

Seasonal variation of phytoplankton community structure is generally understood to be driven by the water circulation dynamics, which varies mainly in accordance to the dry and wet periods in tropical waters (Giani and Figueiredo, 1999; Marinho and Huszar, 2002; Silva, 2004). 
Table 1. Summary of Akaike's information criterion and associated statistics for the nested models for the analysis of species richness of total phytoplankton and different groups of algae. Only the results for the first two best models are listed. Predictors: 1) water transparency; 2) $\mathrm{CO}_{2}$; 3) total-N; 4) total dissolved phosphorus; 5) water stability (temperature differences between surface and mean depth); 6) chlorophyll- $a$; 7) autoregressive covariate. In the model estimated for Bacillariophyceae, the seventh predictor is silicates and the last predictor and 8) is the autoregressive covariate. $\Delta \mathrm{AIC}_{\mathrm{c}}=\mathrm{AIC}$ differences relative to the smallest AIC value in the set of R models; wi = Akaike weights.

\begin{tabular}{lcccc}
\hline & Predictor & $\Delta$ AICc & wi & w1/w2 \\
\hline Total & $3,4,7$ & - & 0.192 & - \\
phytoplaknton & $3,4,5,7$ & 1.579 & 0.087 & 2.21 \\
Bacillariophyceae & $2,3,4,5,7,8$ & - & 0.056 & - \\
& $2,3,4,5,8$ & 0.668 & 0.040 & 1.40 \\
Chlorophyceae & 4,7 & - & 0.140 & - \\
& $3,4,7$ & 0.132 & 0.132 & 1.06 \\
Cryptophyceae & $2,4,5,7$ & - & 0.145 & - \\
& $2,3,4,5,7$ & 0.883 & 0.093 & 1.56 \\
Cyanophyceae & $4,6,7$ & - & 0.138 & - \\
& $3,4,6,7$ & 1.778 & 0.057 & 2.42 \\
Euglenophyceae & $2,3,4,7$ & - & 0.126 & - \\
& $2,4,7$ & 0.794 & 0.085 & 1.48 \\
Others & $3,4,6,7$ & - & 0.139 & - \\
& 6,7 & 1.720 & 0.059 & 2.36 \\
\hline
\end{tabular}

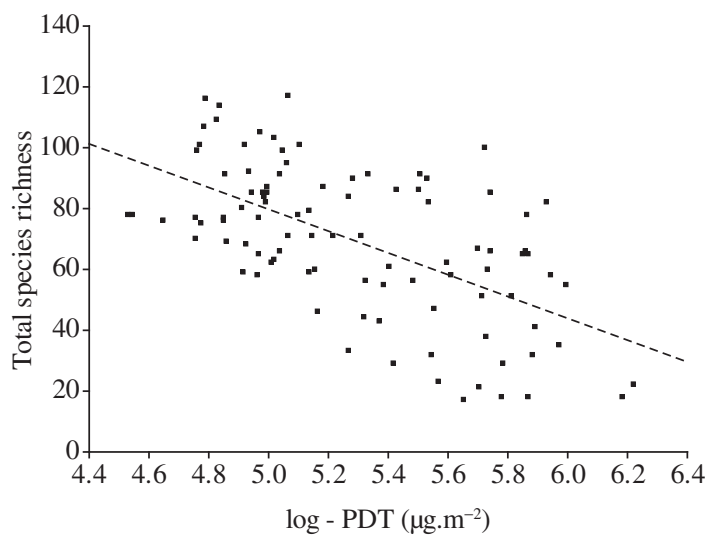

Figure 3. Relationship between phytoplankton total species richness and water column integrated total dissolved phosphorus.

At first, the phytoplankton community dynamics in Garças Reservoir was also considered to be under the effect of seasonal-related factors. For instance, Fonseca (2005) recognized a clear pattern of permanent stratification during the rainy period of 1997 with presence of a monospecific Cyanobacteria bloom (Sphaerocavum brasiliense Azevedo and Sant'Anna). During the dry period, with the water mixture, contribution of other al- gal groups increased leading to a high species richness. Similar patterns were also recorded in previous studies in Garças Reservoir (Sant'Anna et al., 1997; Ramírez and Bicudo, 2002; 2005). Thus, in general, before the water hyacinth outbreak, periods of phytoplankton bloom associated with low species richness were restricted to the stratification periods (spring and/or summer), when higher values of $\mathrm{TP}, \mathrm{CO}_{3}^{-}, \mathrm{pH}$ and chlorophyll- $a$ were registered.

Drastic limnological changes occurred following the fast expansion and sudden removal of Eichhornia crassipes (Martius) Solms (Bicudo et al., 2006; Bicudo et al., 2007). Before macrophytes removal, reservoir was characterised by the lowest algal biomass, highest transparency, lowest water stability and P availability (Bicudo et al., 2007). The first sharp decrease in total biodiversity marked the change from phase I to II, when macrophytes covered up to 40$70 \%$ of the water surface. Phytoplankton composition also changed from $\mathrm{S}$ to $\mathrm{C}$-strategists, being dominated by flagellated opportunistic forms (Crossetti, 2006).

According to Bicudo et al. (2007), macrophyte removal triggered feedback mechanisms enhancing eutrophication, most probably by changing internal $\mathrm{P}$ cycling. Heavy cyanobacterial blooms then occurred throughout almost the entire phase III, which, in turn, enhanced thermal stability and also P release during the extended bottom anoxia periods. This abrupt change from phase II to III, when the reservoir shifted to hypertrophic (Bicudo et al., 2006), was also followed by a high decrease in species richness. Yet, over the third phase, highest decreases in total species richness, mainly during the springs, occurred simultaneously to the highest Cyanobacteria blooms, particularly of Cylindrospermopsis raciborskii (Woloszýnska) Seenaya and Subba Raju (mean contribution 40,929 $\mathrm{mm}^{3} \cdot \mathrm{m}^{-2}$; $\mathrm{n}=64$ months) and Microcystis aeruginosa (Kützing) Kützing (mean contribution $170,876 \mathrm{~mm}^{3} \cdot \mathrm{m}^{-2} ; \mathrm{n}=64$ ) (Crossetti, 2006), which increased 10 and 1,030 times from phase II to phase III, respectively. Most probably, increased turbidity due to phytoplankton blooms suppressed all other algal groups, so that at the end of phase III even the Cyanobacteria species richness decreased.

Decreases in species richness after Cyanobacteria blooms were also detected in other studies (Padisák, 1993; Calijuri and Santos, 1996). It is well known that Cyanobacteria display a wide number of ecological strategies that allow their dominance in aquatic ecosystems (Pearl, 1988; Shapiro, 1990; Scheffer et al., 1997; Smith, 2001). In some systems, stability induces their growth allowing fluctuation under optimal light conditions and re-suspension inhibition of the no-floating competitive species (Viner, 1985). Moreover, in systems dominated by Cyanobacteria populations, self-shading has a considerable impact on the potential productivity and might affect all phytoplankton community structure (Hubble and Harper, 2001).

Total dissolved phosphorus was included in most of the best selected models used to analyze the temporal patterns in species richness. Interestingly, the negative 


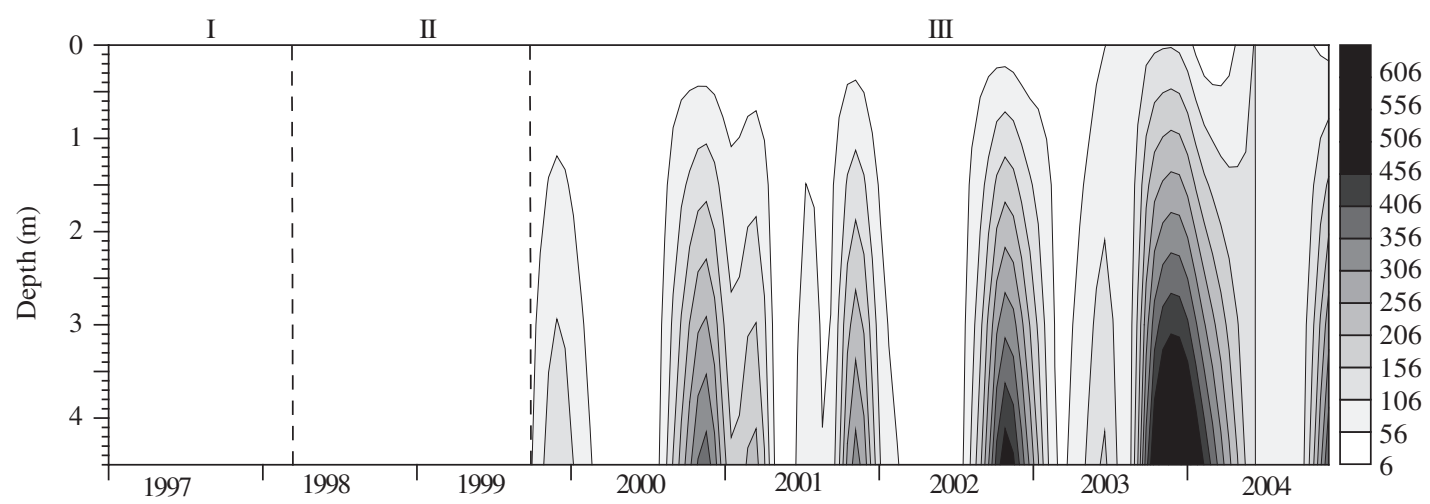

Figure 4. Depth-time diagram of total dissolved phosphorus $\left(\mu \mathrm{gP} \mathrm{L}^{-1}\right)$ recorded over 8 years in the Garças Reservoir. Vertical lines indicate the end of each phase.

relationship between phytoplankton richness and P levels was consistent with previous studies (Leibold, 1999; Dodson et al., 2000).

Summarizing, species richness in Garças Reservoir clearly changed among phases. During phase I, stratification months (spring) favored episodic Cyanobacteria blooms, followed by a decrease in biodiversity. During the macrophytes outbreak (phase II), system alterations enhanced disturbance to break up Cyanobacteria blooms, thus favoring the establishment of pioneer species. Immediately after macrophyte removal, Cyanobacteria dominance suppressed all other algal groups, leading to a very conspicuous decrease in species richness. Intensification of internal feedback mechanisms over phase III together with increase in water stability, $\mathrm{P}$ availability and persistence of Cyanobacteria blooms (Bicudo et al., 2007) clearly promoted the sharp decrease in total species richness. Probably, light was a limiting resource due to the heavy Cyanobacteria biomass at the surface, which reached values greater than $4,000 \mathrm{~mm}^{3} . \mathrm{L}^{-1}$ (Bicudo et al., 2007). Therefore, the degraded state of Garças Reservoir led to a total richness decrease at the end of phase III, including Cyanobacteria richness decrease.

The change from the eutrophic to the hypertrophic state led to a reduction of approximately 70 species (average $37 \%$ ). Such a figure may, however, be underestimated considering the lack of past information when the reservoir was oligo/mesotrophic and colonized by submerged macrophytes and had different habitats availability.

Present data show that biodiversity loss following trophic change was not a single dimension of a single factor but, rather, a template of factors (e.g. light, stability) covarying in consequence of the larger levels of biomass supported in the reservoir. Under the drastic consequences of an advanced eutrophication process on the biodiversity of Garças Reservoir, recovering management efforts will be even more challenging and a hard task to accomplish.

Freshwater ecosystems have been experiencing declines in biodiversity far greater than those recorded in terrestrial ecosystems and, if trends in human demands for water remain unaltered, species losses will surely continue at current rates. Furthermore, their conservation and management are critical to the interests of the entire Mankind, as long as biodiversity constitutes a valuable natural resource in economical, cultural, aesthetic, scientific and educational terms (Dundgeon et al. 2006).

\section{References}

AGOSTINHO, AA., THOMAZ, SM. and GOMES, LC., 2005. Conservation of the biodiversity of Brazil's inland waters. Conserv. Biol., vol. 19, no. 3, p. 646-652.

BARBOSA, FAR., RYLANDS, AB. and OLIVEIRA, SJ., 1993. Drastic decrease in algal diversity caused by human impact on an urban lake in southeast Brazil. Verh. int. Verein. theor. angew. Limnol., vol. 25, no. 2, p. 939-941.

BICUDO, DC., FONSECA, BM., BICUDO, CEM., BINI, LM. and ARAÚJO-JESUS, T., 2006. Remoção de Eichhornia crassipes em um reservatório tropical raso e suas implicações na classificação trófica do sistema: estudo de longa duração no Lago das Garças, São Paulo, Brasil. In TUNDISI, JG., MATSUMURA-TUNDISI, T. and SIDAGIS-GALLI, CV. (Eds.). Eutrofização na América do Sul: causas, consequiências e tecnologias para gerenciamento e controle. São Carlos: Instituto Internacional de Ecologia. p. 413-438.

BICUDO, DC., FONSECA, BM., BINI, LM., CROSSETTI, LO., BICUDO, CEM. and ARAÚJO-JESUS, T., 2007. Undesirable side-effects of water hyacinth control in a shallow tropical reservoir. Freshwat. Biol., vol. 52, no. 6, p. 1120-1133.

BURNHAM, KP. and ANDERSON, DRO., 2002. Model selection and multimodel inference: a practical informationtheoretic approach. 2 ed. New York: Springer-Verlag.

CALIJURI, MC. and SANTOS, ACA., 1996. Short-term changes in the Barra Bonita reservoir (São Paulo, Brazil): emphasis to the phytoplankton communities. Hydrobiologia, vol. 330 , no. 3, p. 163-175.

CROSSETTI, LO., 2006. Estrutura e dinâmica da comunidade fitoplanctônica no período de oito anos em ambiente eutrófico raso (Lago das Garças), Parque Estadual das Fontes do Ipiranga, São Paulo. Ribeirão Preto: Universidade de São Paulo. [Doctoral Dissertation]. 
DODSON, SI., ARNOTT, SE. and NOTTINGHAM, KL., 2000. The relationship in lake community between primary productivity and species richness. Ecology, vol. 81, no. 10, p. 2662-2679.

DUDGEON, D., ARTHINGTON, AH., GESSNER, MO., KAWABATA, ZI., KNOWLER, DJ., LÉVÊQUE, C., NAIMAM, RJ., PRIEUR-RICHARD, AH., SOTO, D., STIASSNY, MLJ. and SULLIVAN, CA., 2006. Freshwater biodiversity: impotance, threats, status and conservation challenges. Biol. Rev., vol. 81, no. 2 , p. 163-182.

FONSECA, BM., 2005. Diversidade fitoplanctônica como discriminador ambiental em dois reservatórios rasos com diferentes estados tróficos no Parque Estadual das Fontes do Ipiranga, São Paulo. São Paulo: Universidade de São Paulo. 208 p. [Doctoral Dissertation].

GIANI, A. and FIGUEIREDO, CC., 1999. Recorrência de padrões sazonais do fitoplâncton num reservatório eutrófico (Reservatório da Pampulha, MG). In HENRY, R. (Ed.). Ecologia de Reservatórios: estrutura, função e aspectos sociais. Botucatu: FAPESP, FUNDBIO. p. 531-550.

HUBBLE, DS. and HARPER, DM., 2001. Impact of light regimen and self-shading by algal cells on primary productivity in the water column of a shallow tropical lake (Lake Naivasha, Kenya). Lakes Resvrs. Res. Mgmt., vol. 6, no. 2, p. 143-150.

JOHNSON, JB. and OMLAND, KS., 2004. Model selection in ecology and evolution. Trends Ecol. Evol., vol. 19, no. 2, p. 101-108.

LEIBOLD, MA., 1999. Biodiversity and nutrient enrichment in pond plankton communities. Evol. Ecol. Res., vol. 1, p. 73-95.

MARINHO,MM. andHUSZAR,VLM.,2002.Nutrientavailability and physical conditions as controlling factors of phytoplankton composition and biomass in a tropical reservoir (southeastern Brazil). Arch. Hydrobiol., vol. 153, no. 3, p. 443-468.

MARTINELLI, LA., SILVA, AM., CAMARGO, PB., MORETTI, R., TOMAZELLI, AC., SILVA, DML., FISCHER, EG., SONODA, KC. and SALOMÃO, MSMB., 2002. Levantamento das cargas orgânicas lançadas nos rios do estado de São Paulo. Biota Neotropica, vol. 2, no. 2, p. 1-18.

PADISÁK, J., 1993. The influence of different disturbance frequencies on the species richness, diversity and equitability of phytoplankton in shallow lakes. Hydrobiologia, vol. 249, no. 1-3, p. 135-156.

PEARL, HW., 1988. Growth and reproductive strategies of freshwater blue-green algae (Cyanobacteria). In SANDGREN, CD. (Ed.). Growth and reproductive strategies of freshwater phytoplankton. Cambridge: Cambridge University Press. p. 261-315.

RAMÍREZ, JJ. and BICUDO, CEM., 2002. Variation of climatic and physical co-determinants of phytoplankton community in four nictemeral sampling days in a shallow tropical reservoir, southeastern Brazil. Braz. J. Biol. = Rev. Bras. Biol., vol. 62, no. 1 , p. 1 - 14 .
-, 2005. Diurnal and spatial (vertical) dynamics of nutrients $(\mathrm{N}, \mathrm{P}, \mathrm{Si}$ ) in four sampling days (summer, fall, winter, and spring) in a tropical shallow reservoir and their relationships with the phytoplankton community. Braz. J. Biol. $=$ Rev. Bras. Biol., vol. 65, no. 1, p. 141-157.

RANGEL, TFLVB., DINIZ-FILHO, JAF. and BINI, LM., 2006. Towards an integrated computational tool for spatial analysis in macroecology and biogeography. Global Ecol. Biogeogr., vol. 15 , no. 4 , p. 321-327.

REYNOLDS, CS., PADISAK, J. and SOMMER, U., 1993. Intermediate disturbance in the ecology of phytoplankton and the maintenance of species diversity: a synthesis. Hydrobiologia, vol. 249, no. 1-3, p. 183-188.

RODRIGO, MA., ROJO, C. and ARMENGOL, X., 2003. Plankton biodiversity in a landscape of shallow water bodies (Mediterranean coast, Spain). Hydrobiologia, vol. 506-509, no. $1-3$, p. 317-326.

SANT'ANNA, CL., SORMUS, L., TUCCI, A. and AZEVEDO, MTP., 1997. Variação sazonal do fitoplâncton do Lago das Garças, São Paulo, SP. Hoehnea, vol. 24, no. 1, p. 67-86.

SCHEFFER, M., 2001. Alternative attractors of shallow lakes. The Scientific World, vol. 1, p. 254-263.

SCHEFFER, M., RINALDI, S., GRAGNANI, A., MUR, LR. and VAN NES, EH., 1997. On the dominance of filamentous Cyanobacteria in shallow, turbid lakes. Ecology, vol. 78, no. 1, p. $272-282$.

SHAPIRO, J., 1990. Current beliefs regarding dominance by blue-greens: the case for the importance of $\mathrm{CO}_{2}$ and $\mathrm{pH}$. Verh. int. Verein. theor. angew. Limnol., vol. 24, no. 1, p. 38-54.

SILVA, LHS., 2004. Fitoplâncton de um pequeno reservatório eutrófico (Lago Monte Alegre, Ribeirão Preto, SP): dinâmica temporal e respostas à ação do zooplâncton e peixes. Rio de Janeiro: Universidade Federal do Rio de Janeiro. 219 p. [Doctoral Dissertation].

SMITH, VH., 2001. Blue-green algae in eutrophic fresh waters. Lakeline: Spring. p. 34-37.

SUDING, KN., GROSS, KL. and HOUSEMAN, GR., 2004. Alternative states and positive feedbacks in restoration ecoloy. Trends Ecol. Evolut., vol. 19, no. 1, p. 46-53.

TUNDISI, JG., 2003. Água no Século XXI: enfrentando a escassez. São Carlos: RiMa; IIE. 248 p.

TUNDISI, JG. and MATSUMURA-TUNDISI, T., 2003. Integration of research and management in optimizing multiple uses of reservoirs: the experience in South America and Brazilian case studies. Hydrobiologia, vol. 500, no. 1-3, p. 231-242.

UTERMÖHL, H., 1958. Zur vervollkommnung der quantitativen phytoplankton-methodik. Mitt. int. Verein. theor. angew. Limnol., vol. 9, no. 1, p. 1-38.

VINER, AB., 1985. Thermal stability and phytoplankton distribution. Hydrobiologia, vol. 125, no. 1, p. 47-69. 